\title{
Percepetion and attitude towards tree growing in east Nepal
}

\author{
Annapurna N. Das ${ }^{1}$
}

\begin{abstract}
Information on existing tree growing practices were collected from seven villages of Morang District and six that of Dhankuta through Rural Appraisals. The tree species that the rural households were willing to introduce into their farmland have been listed. Results indicated that there is a common interest among rural households of both the Terai and Middle Hills towards growing bamboo in private farmlands. Rural households in the Terai preferred timber species such as sissoo (Dalbergia sissoo) and fruit trees which have high commercial values, whereas Middle Hills households preferred fodder trees.
\end{abstract}

Keywords: Dalbergia sissoo, Alnus nepalensis, Bamboo, Terai, Middle Hills, fodder, fruit trees.

he scarcity of forest products and the price increase of wood products in market and the regulatory policies of the forest products in the adjoining areas, etc. have led to an increase in tree cultivation in the Terai (Soussan et ai, 1991; Kanel, 1995). The perceived shortage of trees and forest products also changed the attitude of farmers towards tree planting which increased in tree cover in many private farms of eastern and central Nepal (Carter, 1991; Carter and Gilmour, 1989; Hobley, 1990; Carter and Gronow, 1992).

Nepal's Master Plan for Forestry Sector has given emphasis to Private Forestry and Community Forestry programmes (HMGN, 1988). It is now increasingly realised that for any intervention which is aimed towards promoting private tree planting, households perception and attitudes should be taken into consideration. The present study aims to collect information on the existing trends and preferences of rural households towards tree planting on private farmland.

\section{Methods}

\section{Selection of}

\section{sites}

Six Village Development Committees (VDCs), viz. Dangraha, Sidhraha, Lakhantai, Tetariya, Motipur and Banigaon of Morang District in the Terai and six (Ankhisalla, Hattikharka, Pakhribas, Murtidhunga, Parewadin and Bhirgaon) that of Dhankuta District in the Middle Hills were selected for the present study. One ward out of nine in each VDC was randomly selected for household survey.
Kerabari, a village at Morang District which is close to national forest is purposively selected to note any differences in the farmers perception and attitudes towards tree growing. People of different ethnic groups who have migrated within the last forty years from the bordering hill districts of east Nepal have settled in here.

The study sites of Dhankuta District have diverse ethnic groups such as Rai, Limbu, Gurung, Magar, Brahmin, Chhetri, Damai and Sarki, and at Morang there are Tharu, Rajbansi, Khawas, Bantas and Mushar.

To enhance the quality of data, a multi-faceted research approach was adopted, combining techniques used in the social sciences such as rural appraisals (RRA and PRA) and those more familiar to biological scientists such as ranking, diagramming, and formal surveys. The use of different methods such as surveys with semistructured interview, focus group meetings, key informant interviews and personal diaries of some households served as a cross-check (triangulation) on the reliability of information obtained from one method against another. They were chosen carefully to combine the collection of qualitative and quantitative information, and permit comparisons between the two. The male and female focus group meetings were conducted along with household survey to build trust between researcher and rural households and to generate additional information which are not possible to obtain through household surveys alone. 
Das

\section{Sampling and Survey Procedure}

Upon making a list of all households and their members, the households were categorised into five different wealth ranks with the help of local informants. Twenty five households were randomly selected from the total households with the proportional representation of all the five wealth ranks. The flexibility adopted to incorporate more households from those categories helped to get a broader picture of the village and household characteristics. The total sample in VDCs was thus between twenty nine to forty-one households. The questionnaires were administered to these selected households. In some cases where the households were not available, another one from the list representing that wealth rank was randomly selected for the study.

Altogether, 199 households were selected for the sample from the 6 Tharu dominated villages at Morang District, 41 households at Kerabari and 208 at Dhankuta District, thus making a total of 448 households.

\section{Results and discussions}

Existing woody perennials in the farmland of the Terai villages

Households in the Terai villages showed high interest in tree planting. Those with larger farms have more woody perennials than smaller farms. In

\section{Banko Janakari, Vol. 9, No. 2}

general, they have introduced multipurpose tree species. The multiple production of any single tree species was an important criterion of selection. Tree species grown are also considered a source of income. Households with large farms planted a wider variety of tree species than those with smaller farms. Even some of the Sukumbasi (landless) had planted a few trees on the very small patch of public land that they have illegally occupied. Most wealth rank 1 households, which usually have more than 3 hactares of land, had planted woody perennials in baginchba (home garden) and in blocks.

More than sixty species grown on farmlands were recorded. The commonest place to grow trees was the homestead where they can be regularly supervised. They were not generally seen on the boundaries of paddy fields which were usually far. The commonly grown woody perennials in the six Terai villages are given in Table 1.

Bamboo are the most widely distributed species in these villages followed by Dalbergia sissoo. Other than bamboo and sissoo, most other tree species on the farmland were the sources of edible fruits. The most common are Mangifera indica, Artocarpus beterophyllus, Anthocephalus cadamba and Cocos nucifera. In all villages except Motipur, bamboo are the most widespread species followed by sissoo and mango. Bamboo were considered valuable in terms of construction materials and income they provide during hardship.

Table 1 : The most widely distributed woody perennials on private farmlands

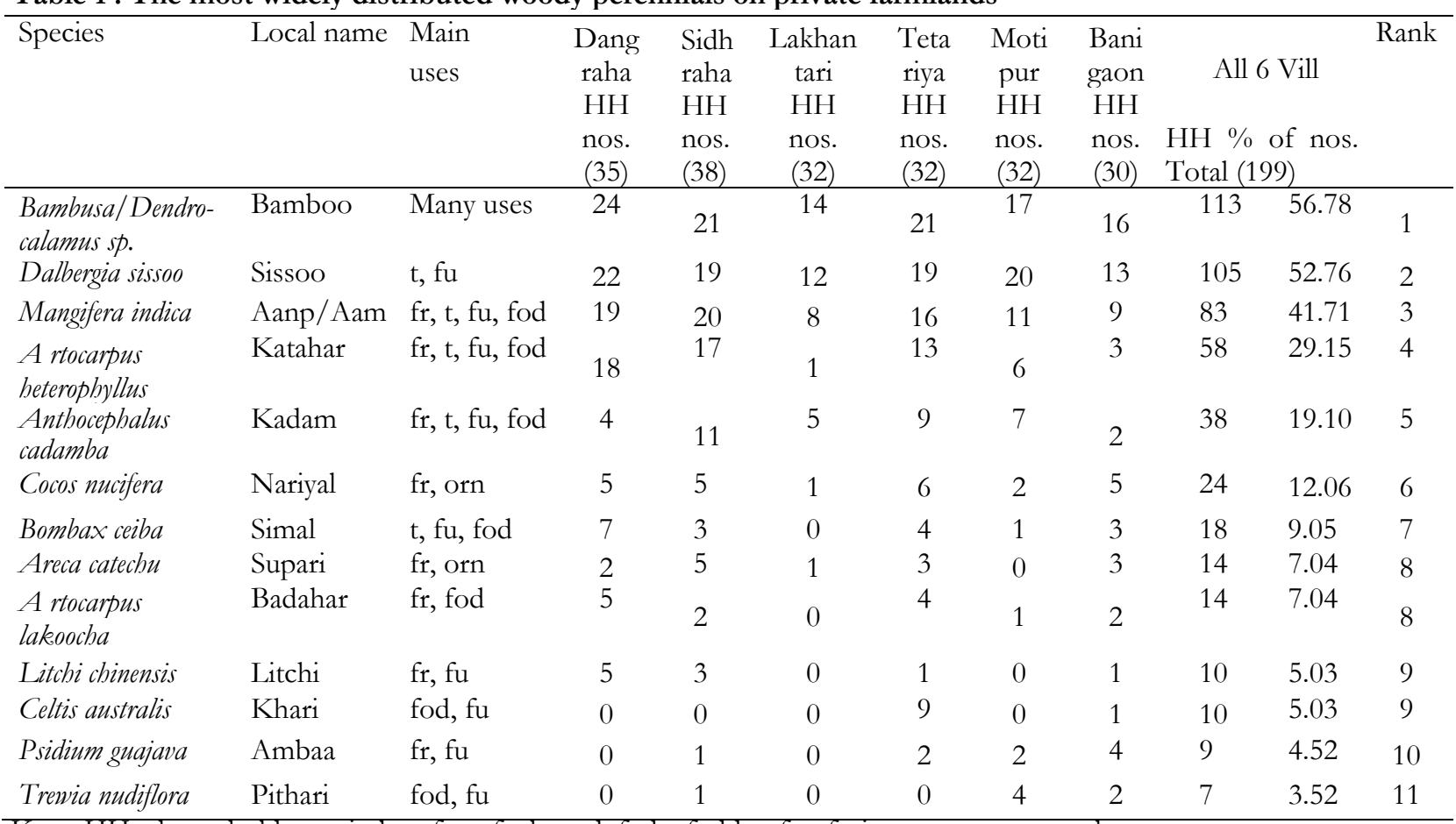




\section{Banko Janakari, Vol. 9, No. 2}

Most of these woody perennials are important sources of fruits and timber than as fuelwood or fodder. However, they are also a source of fodder and fuel during scarcity. As there is a shortage of timber and other forest products, the interest of tree planting, including bamboo which take a short time to establish and grow, has considerably increased in recent years.

Even though Kerabari is surrounded by public forest, there are many woody perennials on the farmland (Table 2). Bamboo were the most widely distributed followed by mango, sissoo, tanki (Baubinia purpurea), and coconut. The commonest fodder trees were Baubinia, Artocarpus lakoocha, Ficus lacor, Litsea monopetala and Garuga pinnato. Adina cordifolia and Terminalia bellerica, the wild species were also seen in the farmland. most widely distributed woody perennial was Alnus nepalensis followed by bamboo (Table 3).

The majority of households had introduced more than one bamboo species for multiple uses, including fodder. The other most common species on farmland were Ficus nemoralis, Schima wallichii and Ficus semicordata. Majority of the species were introduced specifically for fodder. Seven of the top ten common species were grown primarily for fodder.

Because of forest degradation, restricted access to forest and with exceeding demand, the interest in tree planting has considerably increased in recent years. The other driving force is the increased market value of construction materials. The choice of species might have been affected by these factors. The other factor governing the choice of species is

Table 2: The most widely distributed woody perennials on the farmland at Kerabari

\begin{tabular}{llllcc}
\multicolumn{1}{c}{ Species } & Local name & \multicolumn{1}{c}{ Uses } & HH No. (41) & \% of total & Rank \\
\hline Bambusa/Dendrocalamus sp. & Bans & Many uses & 24 & 58.54 & 1 \\
Mangifera indica & Aanp/A am & fr, t, fu & 23 & 56.10 & 2 \\
Dalbergia sissoo & Sissoo & t, fu & 21 & 51.22 & 3 \\
Baubinia purpurea & Tanki & fod, fu & 16 & 39.02 & 4 \\
Cocos nucifera & Nariyal & fr, orn & 14 & 34.15 & 5 \\
A rtocarpus heterophyllus & Katahar & fr, t, fod, fu & 13 & 31.71 & 6 \\
Areca catechu & Supari & fr, orn & 13 & 31.71 & 6 \\
Artocarpus lakoocha & Badahar & fr, fod, fu & 10 & 24.39 & 7 \\
Ficus lacor & Kavro & fod, fu & 9 & 21.95 & 8 \\
Psidium guajava & Ambaa & fr, fu & 7 & 17.07 & 9 \\
Litsea monopetala & Kutmiro & fod, fu & 7 & 17.07 & 9 \\
Garuga pinnata & Dabdabe & fod, fu & 7 & 17.07 & 9 \\
Adina cordifolia & Karma & t, fu, fod & 6 & 14.63 & 10 \\
Terminalia bellerica & Barro & t, fod, fu & 3 & 7.32 & 11 \\
\hline \hline
\end{tabular}

\section{The Middle Hills villages}

In the Middle Hills, the commonest place to grow woody perennials is land near settlements, usually the edge of bari (upland) and gullies. The other common place were the edge of terraced land and some scattered trees on khet (lowland). Block planting was very rare in the Middle Hills. Tree growing was more common than in the Terai with the majority of households having at least some woody perennials on the farm. A large number of fodder trees were also found on the farmland. The the ethnic composition and cultural practices. The settlers at Kerabari migrated from Dhankuta and neighbouring hill districts might have brought with them, the farming practices of the Middle Hills.

\section{Bamboo existing on farmland}

The majority of the households in the Terai, Middle Hills and Kerabari were bamboo growers. Bamboo were the most commonly grown species on the private farmland in the Terai and Kerabari and the second most commonly grown woody perennial in the Middle Hills (Table 4). 


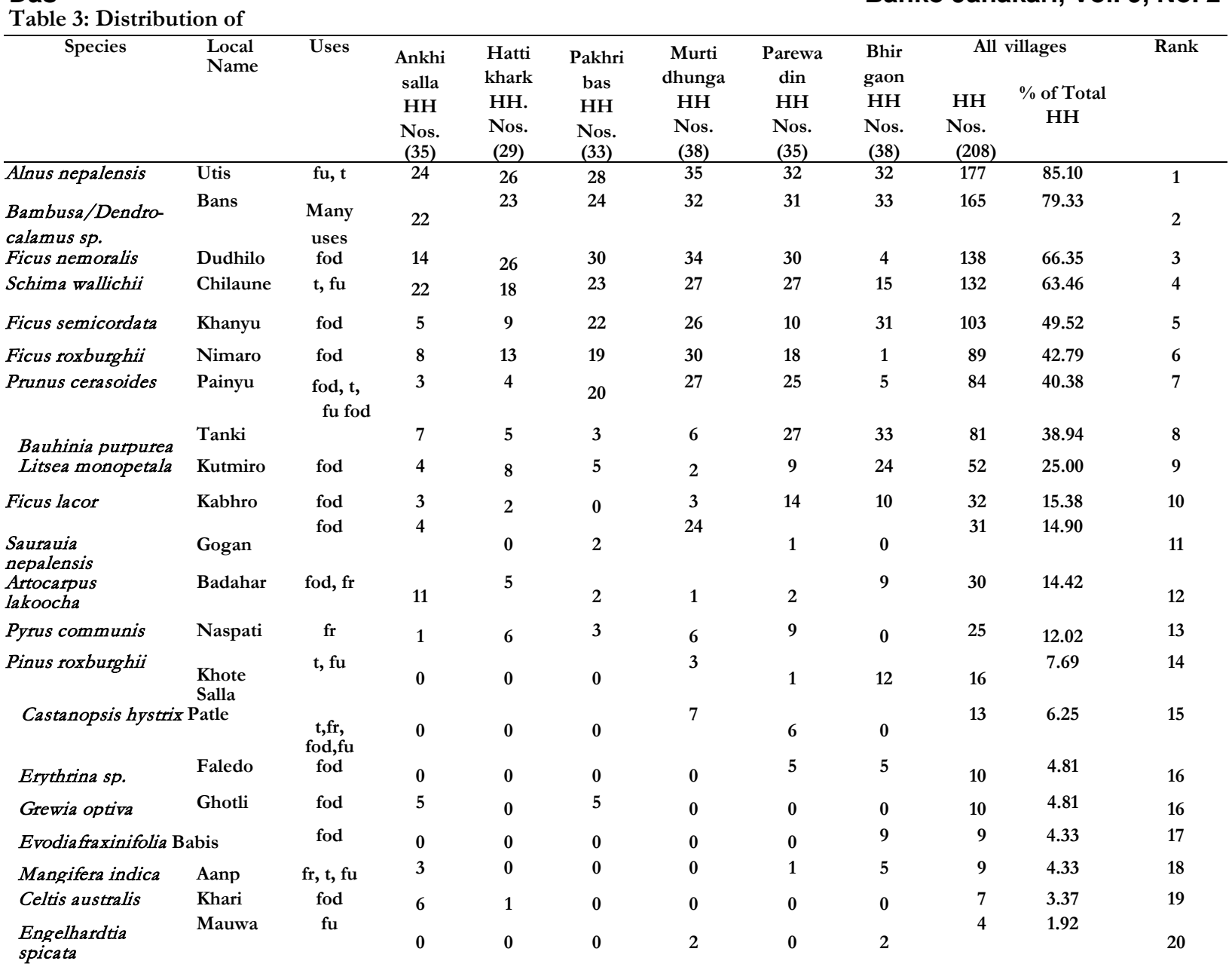

Keys: $\mathrm{HH}=$ Household, $\mathrm{t}=$ timber, fod $=$ fodder, $\mathrm{fu}=$ fuelwood, fr=fruit.

The most common bamboo species was Malbans (Bambusa nutans) which can grow in a wide range of climatic conditions from the Terai to 1800 metres. However, the best growing conditions for this species are in the altitudinal range $1000-1500 \mathrm{~m}$. Among the bamboo growers, $92 \%$ in the Terai have at least one bamboo clump of Malbans on their farmland. In the Middle Hills and at Kerabari, it was even higher with $96.4 \%$ and $100 \%$ respectively, showing the popularity of this versatile species.

In the Tharu villages, Malbans was grown in combination with Japhta bans (Bambusa tuldd) and Bholka bans \{Bambusa balcooa) near home in bansbari/bansbitti (bamboo garden) and homegarden by the wealthier households and in the backyards or small homegarden by the poorer households.

In the Middle Hills, other than Malbans, eight other

Table 4: The most widely distributed bamboo species on the farmlands of the study sites

\begin{tabular}{|c|c|c|c|c|}
\hline \multirow[b]{2}{*}{ Speices } & \multicolumn{3}{|c|}{$\%$ of growers } & \multirow[b]{2}{*}{ Uses } \\
\hline & Terai & Middle Hills & Kerabari & \\
\hline Bambusa nutans & 91.96 & 96.36 & 100.00 & Construction, fencing, fodder, weaving, fuel \\
\hline B. tulda & 64.29 & 0.00 & 0.00 & Construction, fencing, shoots as vegetables, weaving, fuel. \\
\hline B. balcooa & 44.64 & 0.61 & 0.00 & Construction, fuelwood, fodder \\
\hline D. strictus & 1.79 & 0.00 & 3.85 & Sticks, fuelwood \\
\hline $\begin{array}{l}\text { Dendrocalamus } \\
\text { hamiltonii }\end{array}$ & 0.00 & 65.45 & 0.00 & Weaving, ropes, fodder \\
\hline D. hooketii & 0.00 & 49.70 & 0.00 & Construction, fodder, shoots as vegetables \\
\hline $\begin{array}{l}\text { D. hamiltonii varedulis } B \text {. } \\
\text { nepalensis }\end{array}$ & 0.00 & 16.97 & 0.00 & Shoots as vegetables, weaving, ropes, fodder \\
\hline D. hamiltonii vat. undulatus & 0.00 & 9.09 & 0.00 & Construction, shoots as vegetables, fodder. \\
\hline Drepanostachyum sp. & 0.00 & 6.06 & 0.00 & Weaving, fodder \\
\hline A mpelocalamus patellatis & 0.00 & 4.24 & 0.00 & Weaving, fodder \\
\hline
\end{tabular}


Banko Janakari, Vol. 9, No. 2

Table 5: Species preferred for planting in the Terai

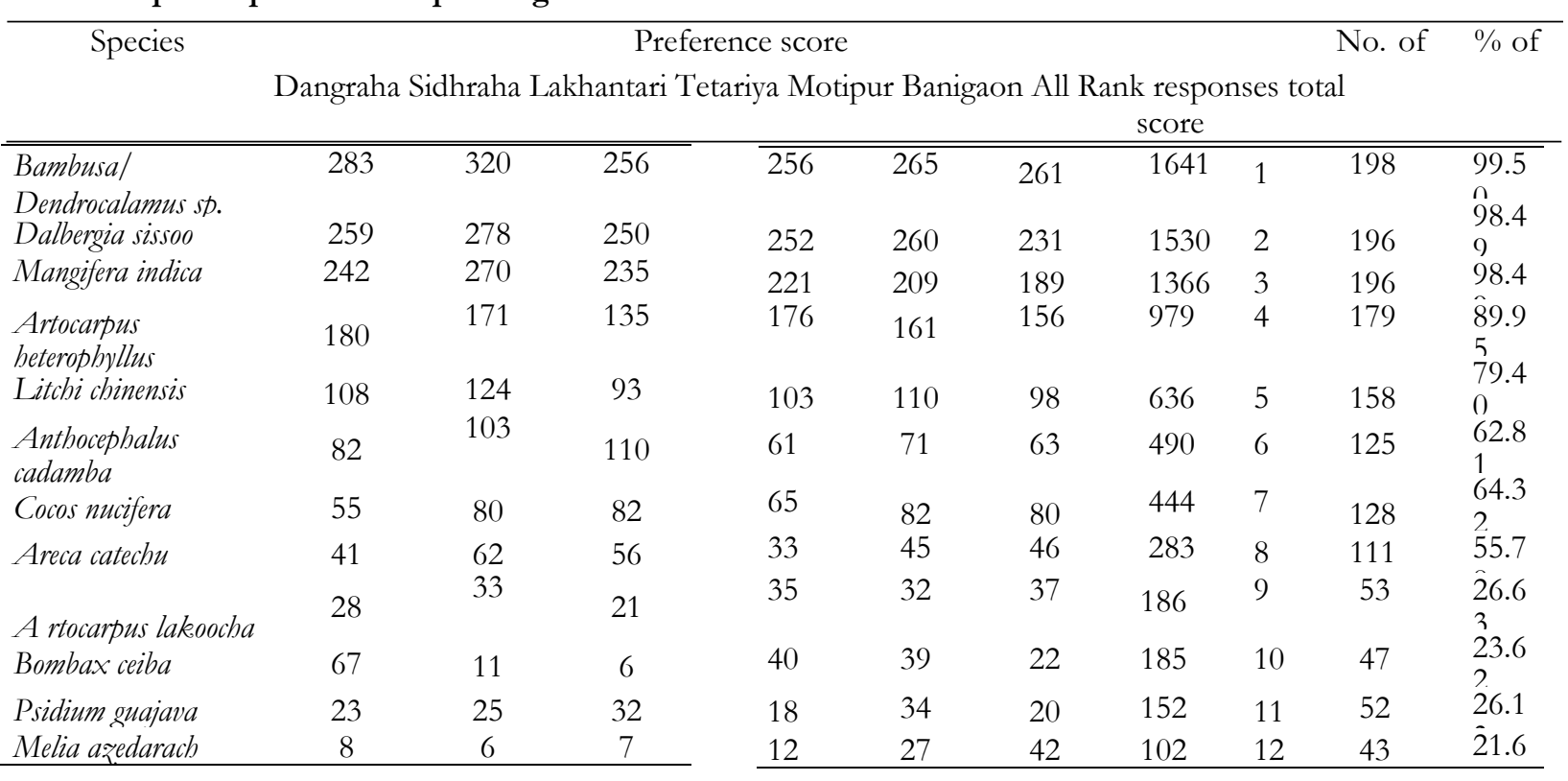

bamboo species were grown on farmland (Table 4). It is evident that the majority of growers have introduced more than one bamboo species in relation to altitudinal range. Malbans was grown on the farmland below 1800 m. whereas Kalo bans was grown above 1500 m. Nigalo (Arundinaria sp.) was introduced above 1900 m. Other than nigalo and kalo bans, all other species were common in the altitudinal range of $1200-1800 \mathrm{~m}$. where most of the settlements were found. The most popular combination of bamboo species being grown in the farmland was Malbans, Choya bans and Kalo bans. The commonest place for growing bamboo was gullies followed by the edge of bari. The introduction of more than one bamboo species seemed related to differen uses. For example, the Tama bans was meant for making vegetable from new shoots and choya bans for tying splits and joints and in house construction. Kalobans and Dhungre bans are used for support poles in house construction.

At Kerabari only Malbans was grown. One household had planted Laathi bans (D. strictus).

\section{Choice of species for planting}

It is now widely accepted that any successful intervention for the promotion of tree planting programmes will need the support of the people. Hence, their perception and attitude towards species is an important aspect of study.

In the Terai, bamboo was the most preferred species by all. It received the highest score in all sampled villages except Motipur where it was ranked second to sissoo. The species closest to bamboo were sissoo and mango followed by katahar, coconut and litchi (Table 5). The majority of households mentioned two or three different bamboo species. Malbans was the most preferred for planting. The individual preference scores of jaftha bans and bholka bans were higher than many of the species.

The choice of fodder appears not to be so important. This is in contrast to the Middle Hills and Kerabari with a large number of fodder species in the top ten.

The much less preferred species for private planting were Leucaena leucocephala, Syzygium cumini, Albizzia sp., Citrus sp., Citrus sp., Tectona grandis, and Acacia nilotica. The least preferred (5\%) species for planting is Shorea robusta.

The species preferred for planting in the Middle Hills are given in Table 6. Bamboo was the most preferred and received the highest score in all sampled villages except Murtidhunga and Parewadin where it was second to utis.

Species preferred after bamboo were utis, chilaune, dudhilo, nimaro and khanyu. Other than utis and chilaune, all other species in the top ten are important sources of fodder. There are no fruit species in the top ten. Majority of households also ranked different bamboo species in the top nine rather than just mentioning bamboo. Malbans was the species most preferred by almost all households. 


\begin{tabular}{|c|c|c|c|c|c|c|c|c|c|c|}
\hline \multirow[b]{2}{*}{ Speices } & \multicolumn{7}{|c|}{ Preference Score } & \multirow[b]{2}{*}{ Rank } & \multirow{2}{*}{$\begin{array}{c}\text { No. of } \\
\text { responses }\end{array}$} & \multirow{2}{*}{$\begin{array}{l}\% \text { of } \\
\text { total }\end{array}$} \\
\hline & $\begin{array}{c}\text { Ankhi- } \\
\text { salla }\end{array}$ & $\begin{array}{l}\text { Hatti- } \\
\text { kharka }\end{array}$ & $\begin{array}{c}\text { Pakhri- } \\
\text { bas }\end{array}$ & $\begin{array}{l}\text { Murti- } \\
\text { dhunga }\end{array}$ & $\begin{array}{c}\text { Parewa- } \\
\text { din }\end{array}$ & $\begin{array}{l}\text { Bhir- } \\
\text { gaon }\end{array}$ & $\begin{array}{l}\text { Total } \\
\text { score }\end{array}$ & & & \\
\hline $\begin{array}{l}\text { Bambusa/Dendro } \\
\text { calamus sp. Alnus }\end{array}$ & 240 & 217 & 223 & 208 & 180 & 239 & 1307 & 1 & 197 & 94.71 \\
\hline nepalensis & 164 & 142 & 167 & 232 & 194 & 216 & 1115 & 2 & 185 & 88.94 \\
\hline Schima walichii & 114 & 93 & 117 & 174 & 190 & 205 & 893 & 3 & $162^{\prime}$ & 77.88 \\
\hline Ficus nemoralis & 52 & 103 & 112 & 202 & 154 & 7 & 630 & 4 & 135 & 64.9 \\
\hline Ficus roxburgbii & 51 & 103 & 141 & 186 & 97 & 6 & 584 & 5 & 109 & 52.4 . \\
\hline Ficus semicordata & 52 & 127 & 140 & 102 & 61 & 87 & 569 & 6 & 134 & 64.42 \\
\hline Baubinia purpurea & 133 & 28 & 40 & 31 & 120 & 189 & 541 & 7 & 102 & 49.04 \\
\hline Prunus cerasoides & 12 & 69 & 66 & 96 & 98 & 37 & 378 & 8 & 107 & 51.44 \\
\hline Litsea monopetala & 89 & 94 & 13 & 7 & 22 & 117 & 342 & 9 & 73 & 35.10 \\
\hline Ficus lacor & 37 & 30 & 0 & 20 & 75 & 50 & 212 & 10 & 52 & 25.00 \\
\hline
\end{tabular}

The less preferred species for private planting were Pyrus communis, Sauarania nepalensis, Pm\&s roxburghii, Gelds australis, Grewia optiva, Artocarpus lakoocha, Castanopsis bystrix, Albizzia sp., Baubinia variegata, Evodia fraxinifolia and Eucalyptus sp. Percent of households mentioning these species were in the order of $20,16,15,14,11,9,7$ 6,5 and 5 households. The lowest percentage $(4 \%)$ of households preferred Madhuca indica for planting.

There is a sharp distinction between the Terai and Middle Hills in terms of preferrence for fodder. The households in the Terai hardly mentioned fodder species nor ranked them in the top ten, whereas these species were much preferred in the Middle Hills.

\section{Species preferrence at Kerabari}

The species preferred for planting at Kerabari are given in Table 7. Bamboo was the most preferred species for planting with Malbans. The species was popular amongst all wealth ranks and ethnic groups followed by sissoo.

The less preferred species for private planting at

Table 7: Species preferred for planting at Kerabari

\begin{tabular}{lcccc}
\hline \multicolumn{1}{c}{ Species } & Preference score & Rank & No. of responses & \% of total \\
\hline Bambusa nutans. & 321 & 1 & 39 & 95.12 \\
Dalbergia sissoo & 306 & 2 & 39 & 95.12 \\
Mangifera indica & 183 & 3 & 34 & 87.18 \\
Baubinia purpurea & 143 & 4 & 26 & 60.98 \\
A rtocarpus heterophyllus & 125 & 5 & 28 & 68.29 \\
Litsea monopetala & 95 & 6 & 24 & 56.1 \\
Garuga pinnata & 72 & 7 & 20 & 48.78 \\
Cocos nucifera & 71 & 8 & 19 & 46.34 \\
Ficus lacor & 70 & 9 & 17 & 41.46 \\
Litchi chinensis & 69 & 10 & 17 & 41.46 \\
A rtocarpus lakoocha & 59 & 11 & 12 & 29.27 \\
Areca catechu & 46 & 12 & 15 & 36.59 \\
\hline
\end{tabular}

Kerabari were Tectona grandis, Terminalia alata, Bombax ceiba, Shorea robusta Dalbergia latifolia, Terminalia bellerica, Lagerstroemia parniflora, and Psidium guajava. The percentage of households preferring these species were $17,15,15,12,12,10,10$ and 10 respectively. The least preferred species $(7 \%$ each) were Pterocarpus marsupium, Grewia optiva and Citrus sp.

Households ranked fruit trees such as mango, katahar coconut and litchi in the top ten. Timber species other than sissoo are less preferred. Bamboo are considered both an important source of construction materials and for fodder.

At Kerabari the majority of households preferred Malbans. Many species of fodder were also found growing.

The findings suggested that rural households, both in the Terai and the Middle Hills, grow a large number of tree species or woody perennials on the farmland for meeting their various need. Such

\section{Conclusion}




\section{Banko Janakari, Vol. 9, No. 2}

species are important sources of timber/construction material, fodder and fuelwood, fruits and vegetables. Woody perennials are also an important source of income when in need. Bamboo is important for households at both the Terai and Middle Hills. However, preferrence for the tree species varied between the Terai and Middle Hills. In the Terai, fruit trees were preferred over fodder trees whereas in the Middle Hills the case is just reverse. Fodder trees in the Terai is not important partly because of availability of crop residues and because of easy access to markets. Fruit trees are maintained not only for household consumption but also for additional income. Even though sissoo, pines and utis is promoted in the past over bamboo by the Department of Forests, fruit trees are more preferred by the rural households of the Terai. The preference for sissoo may decrease in the near future due to the outbreak of its dieback disease in the Terai (Parajuli et al., 1999).

Once the access increases in the Middle Hills through road network, the Middlehill farmers' preference of growing trees is expected to change. They will probably grow species of high commercial value which has a readymade market such as bamboo and fruit trees.

\section{References}

Carter, A. S. and Gilmour, D. A. 1989. Increase in tree cover on private farmland in Central Nepal. Mountain Research and Development, 9 (4): 381391.

Carter, E. J. 1991. Tree cultivation on private land on the Middle Hills of Nepal. A Thesis

\section{Das}

presented for the $\mathrm{Ph} \mathrm{D}$ degree at the Oxford University, UK.

Carter, E. J. and Gronow, C. J. V. 1992. Strategies for supporting tree cultivation on private land in the Middle Hills of Nepal. Banko Janakari, 3 (4): 13 18.

HMGN 1988. Master Plan for the Forestry Sector in Nepal : Main Report. Ministry of Forest and Soil Conservation Kathmandu, Nepal.

Hobley, M. E. A. 1990. Social Reality, Social Forestry: The case of two Nepalese

Panchayats. A Thesis submitted for the degree of Doctor of Philosophy of the Australian National University, Australia.

Kanel, K. R. 1995. Farmer and tree linkages in the Tera of Nepal. PhD Thesis, Univ. of Minnesota, USA.

Malla Y. B. 1993. Changing role of the forest fesource market: an ignored dimension of community forestry. Banko Janakari, 4 (1): 24-27.

Parajuli, A. V., Bhatta, B., Adhikari, M. K., Tuladhar, J. R., Thapa, H. B. and Juwa,

. 1999. Die-Back disease of Sissoo in Eastern Tarai of Nepal. FIMG Ministry of Agriculture/Winrock International, Kathmandu, Nepal. Report No. 39.

Soussan, J., Gevers, E., Ghimire, K. and O'Keefe, P. 1991. Planning for sustainability: Access to fuelwood in Dhanusha District in Nepal. World Development, 19 (10): 1299-1314. 